\title{
Rationale for Early Psychological Intervention Among Disaster Actors in Nairobi County, Kenya
}

\author{
Eunice K. Ndulu, Dr. Margaret Iyaya \\ School of Disaster Management \& Humanitarian Assistance \\ Masinde Muliro University of Science \& Technology, P.O BOX 190-50100, Kakamega, Kenya \\ Dr. Margaret Iyaya \\ School of Arts and Social Sciences, Masinde Muliro University of Science \& Technology, \\ P.O Box 190-50100 Kakamega, Kenya
}

\begin{abstract}
The prevention of long-term psychological distress following traumatic events is a major concern for all. Providing early psychological intervention in disaster management is one of the major attempts in preventing Posttraumatic stress symptoms, which may lead to Posttraumatic Stress Disorder (PTSD). Traumatic events can have a significant impact on individuals'; families and community's abilities to cope. Intense effect during a traumatic event and its accompanying psychological arousal have been associated with the development of PTSD. The National Disaster Management Policy, 2012 provides an integrated and coordinated disaster Risk management that focuses on preventing the risk of disasters, mitigating their severity, and effective response to disaster recovery. The policy put in place mechanisms to ensure that there is construction and recovery after disaster. However, less emphasis is placed on post-disaster trauma management, counseling services, psychosocial support services, and health services in order to ensure that disaster victims do not suffer from permanent or prolonged disaster-related effects. This study, therefore, sought to evaluate the impact of early psychological intervention in preventing PTSD among disaster actors. Research done in the area has shown very little information if any on psychological aspects in disaster management, yet this is the premises of vulnerability. The specific objective of this study was to assess the rationale for early psychological intervention among disaster actors in Nairobi county, Kenya. The study was guided by two psychological theories; cognitive behavior theory and constructivist self-development theory. Descriptive and correlational survey designs were adopted in the study, and purposive sampling was used to select the disaster actors that comprised of those who provide rescue services, those who provide first aid and those who provide psychosocial support. Directors and deputy directors were also sampled using the same technique. The simple random technique was used to select 400 disaster actors from various disaster response organizations.Purposive sampling was used to select key informants who included directors and deputy directors of disaster operation organizations. Same sampling technique was used in the selection of FGD participants. Data collection employed qualitative and quantitative techniques i.e., questionnaires, interviews, and Focus group discussions. Document analysis guides assisted in gathering secondary data. Reliability of the instruments was done by the test-retest method. The data collected was coded and entered into the computer data sheet using the statistical package for social sciences (SPSS) version 23.0. Descriptive and inferential statistics used in data analysis include frequencies, percentages. A SWOT analysis was also used. Results obtained were presented using tables, graphs, and pie charts. The study then came up with findings which will be significant to the disaster operation organizations in preventing PTSD among disaster actors in the aftermath of disasters in Kenya by giving new insights. The study found out that: the study respondents overwhelmingly favored the need to provide early psychological intervention for disaster management with a percentage of 68 strongly agree and $32 \%$ disagree. SWOT analysis revealed that disaster response organizations were rich with varied strengths and opportunities that were not adequately exploited towards prevention of PTSD among disaster actors. The findings of this study are significant in policymaking and mechanisms pertaining psychological support in recovery after disaster in Kenya emphasis being placed on post-disaster trauma management, counseling and psychosocial support services to ensure that disaster actors do not suffer from permanent or prolonged disaster-related effects.
\end{abstract}

Keywords: Trauma, PTSD, Psychological intervention, Acute stress disorder, disaster actors, SWOT, Vicarious traumatization

DOI: $10.7176 / \mathrm{JEP} / 10-32-08$

Publication date: November $30^{\text {th }} 2019$

\section{Introduction}

Critical life incidents have existed in the entire human history and such events have always been conceptualized in terms of distress and negative outcomes. The prevention of long-term psychological distress following traumatic events is a major concern for all. Providing psychological intervention in disaster management is one of the major attempts in preventing post-traumatic stress symptoms which may lead to post-traumatic stress 
disorder (PTSD).

Traumatic events can have a significant impact on individuals' abilities to cope. Intense effect during a traumatic event and its accompanying psychological arousal have been associated with the development of PTSD. Following traumatic events much emphasis has been placed on physical aspect of the risk of disasters and mitigating their severity. However very little if any has been done on psychological aspect yet this is the premises of vulnerability. In a situation following a traumatic event, it is important that the individual regains emotional control, restores interpersonal communication and recovers a sense of empowerment which strengthens hope and expectation of recovery.

Kenya like the rest of the world has in the recent past experienced a series of traumatic or stressful events which has inflicted psychological wounds among disaster actors as they respond to the disasters. The efficacy of low and medium intensity interventions such as psychological debriefing or first aid skills for psychological recovery and crisis counseling remain unknown. While policies like the national disaster management policy are in place, there is no documented research on the rationale for providing early psychological intervention among disaster actors following disasters in Nairobi county, Kenya.

An alternative approach could involve implementation of a disaster management policy proactively ensuring that there is construction and recovery after disaster emphasis being placed on post-disaster trauma management, counseling services and psychosocial support to facilitate psychological intervention in the event of disasters. This will ensure that disaster actors do not suffer from permanent or prolonged disaster related effects like PTSD.

\subsection{Statement of the problem}

Critical life incidents have existed in the entire human history which has been conceptualized in terms of distress People may or may not experience PTSD after trauma, but they might also experience responses to trauma that are not diagnostically categorized as PTSD. Untreated trauma may lead to acute stress disorder. If this continues for more than three months, it is considered as post-traumatic stress disorder. It is worth noting that if the onset of PTSD symptoms is delayed by six months after a traumatic experience without psychological intervention or support, then the prognosis is likely to be worse.

A Kenya Defense Forces (KDF) psychologist who is a retired major said in an interview by Andrew Renneisien Washington sport, that she has spoken with at least 800 soldiers who suffered from symptoms typical of PTSD who were punished instead of treated. This indicates a knowledge gap on the need for psychological intervention in preventing post-traumatic stress symptoms which may lead to PTSD in disaster management. To contribute towards the closure of this gap, the study attempts to assess the rationale for providing early psychological intervention among disaster actors following disaster.

\section{Literature review}

Hogan \& Najarian (2007) revealed that trauma and PTSD has been associated with poor early psychological intervention and treatment following traumatic events. Joppe (2000) showed that there is little research to guide mental health practitioners in relation to factors that may be associated with improved treatment outcomes among individuals with PTSD especially with disaster actors' population. Trauma is a wound in the mind and heart caused by a life-threatening experience that is characterized by shock, fear or helplessness. Trauma has come to be part our existence (Okpalaenwe,2016). Untreated trauma may lead to acute stress disorder and if the symptoms continue for more than three months, it is considered as post-traumatic stress disorder (Ministry of Health Mental health training manual $1^{\text {st }}$ Ed. (2016).

Post-traumatic stress disorder symptoms may become disabling, particularly if those affected lack adequate psychological intervention to allow them to voice their traumatic experiences. Hidden trauma can ultimately destroy many people including those who respond to disasters. A traumatic event will have many direct and indirect victims. Individuals who are at the scene of horrific event may experience traumatic stress which may also have an impact on many others including disaster actors. In organizations, traumatic stress will lead to communication breakdown, a decrease in morale and group cohesiveness, workplace tension and conflict, excessive absenteeism and ultimately a decrease in productivity (American Psychological Association, 2015).

Efforts to address psychological needs arrive in weeks, months and years following traumatic events after emotional scars have formed and after people are labeled with traumatic stress disorder. Techniques need to be developed to demobilize, defuse and debrief people after disengagement from crisis from a traumatic event.

Notwithstanding, there is little practical strategies to help disaster actors during a traumatic experience a time when these professionals are highly suggestible, impressionable and vulnerable.

Stress reactions to severe events have been recognized for centuries but post-traumatic stress disorder (PTSD) was not accepted as a clinical diagnosis until 1980 (American Psychological Association,2000). As traumatic events continue to be reported across the globe for instance terrorist attacks, governments may be overwhelmed by this growing challenge and may be forced to increase funding as a way of mitigating long-term 
emotional suffering during and in the wake of a traumatic event especially for the actors. There is need for a repertoire of helping approaches beyond the physical and safety needs of people and raise the level of psychological care.

Studies across the world show that psychological casualties following disasters are many. For instance, Rugero \& Vos (2013) reported that in the Sarin gas attack in Tokyo 1995, 12 people died, 900 received medical treatment and 900 people presented with psychological complaints ranging from insomnia, anger rage and hyper vigilance. Lopez \& Pineda (2011) observed that in Oklahoma City bombing in 1995, there were 168 fatalities but over 8000 individuals sought psychological intervention. In a study conducted on 29,000 individuals who performed rescue work at the World Trade Centre site in New York after the September 11 2001, terrorist attack found that working on the site, working for long period and sustaining an injury increased the risk of having post-traumatic stress disorder 2-3 years later (American Psychological Association,2000). The psychological impact of September, 112001 terrorist attack in New York using a sample of 3271 adults, the inclusion criterion was those who were evacuated from the site of the attack. Recruitment of the participants was done from the world trade centre health registry using simple random sampling. Those who had direct exposure to the terrorist attack had $1.5 \%$ trauma symptom prevalence 6 months after the attack.

The rescue workers had trauma prevalence of $11.1 \%$ eleven months after the attack while the pentagon workers reported trauma prevalence of $14 \%$ seven months after the attack.

At a meeting of the European society for traumatic stress in 2013, a symposium was held that brought together international researchers and clinicians who were involved in psychosocial responses to disaster. A total of six disasters that occurred in five countries were presented and discussed. Lessons learned from these disasters included the need to: tailor psychosocial response to the specific disaster; proactively address barriers in access to psychosocial care especially for those responding to disasters; extend the roles for mental health professionals; efficiently coordinate and integrate disaster response services. Provision of psychological support to disaster affected populations should be recognized as a key strategy in mitigating the adverse mental health effects of disasters such as PTSD. Atwoli et al., (2015) reported comparative findings of trauma prevalence in selected different cultures.

The study was conducted in South Africa using a sample of 4315 adults of different nationalities who had experienced different traumatic events like death of loved ones, war trauma, physical violence, sexual violence and accidents. After the analysis, leading was North Ireland with a prevalence of $17.6 \%$ followed by Spain $3.3 \%$, South Africa at $2.5 \%$ and Italy $2.5 \%$ prevalence. However, the study did not sample participants from disaster actors which is the focus of the current study.

In Kenya studies on trauma prevalence have been conducted reporting relatively higher rates of posttraumatic symptoms with focus on events such as grief, rape and violence among many others. ( Karsberg\& Elklet, 2012 reported trauma symptoms prevalence rate of $34 \%$ in a sample of 477 Kenya rural Youth. A study on 1565 orphaned children in Uasin Gishu County reported post-traumatic symptoms prevalence at $28 \%$ in street children, $15 \%$ among house-holds and $11 \%$ among children in children homes (Atwoli \& Braitstein, 2014).

Another study in Maseno on 1190 adults with exposure to severe trauma reported $10.6 \%$ trauma symptoms prevalence (Jenkins, Kingora \& Ogutu, 2015). A comparative study examining prevalence of psychopathology in workers responding to the 1998 US embassy bombing in Nairobi and 1995 Oklahoma bombing showed 22\% prevalence of PTSD and 27\% of depression symptoms (Zhang, Narayanan, Lee, Thielman\& North, 2016). The study reports that Nairobi disaster rescue workers were 4 times more symptomatic than Oklahoma workers. The high prevalence of trauma among participants in Nairobi has not been explored.

The current study's focus on prevention of posttraumatic symptom prevalence is timely in contributing to this discussion. Most of the studies cited focused on prevalence of trauma experienced by victims and survivors of traumatic events emphasis being laid on physical aspect unlike the current study that has focused on trauma affecting disaster actors. Although most evident is following east and western world, Kenyan people are expecting more and more psychological support following traumatic events. Disaster actors experience the same psychological symptoms as the survivors as they could be haunted by people they were unable to save, by images of the injured or massive nature of destruction which is termed as vicarious traumatization and thus may need as much help and psychological support as the survivors whom they are assisting (Hellmich, 2013).

Disasters are numerous and are by their very nature a serious threat to the health and well-being of the people involved. The world disaster report 2001 states that 256 million people were affected by disasters in 2001 . The big disasters make the news -papers, but the less well publicized, smaller disasters are just as devastating in their effect on the lives and health of the affected population. Critical events such as conflicts, wars, accidents occur with social and psychological consequences that often undermine peoples' ability to carry on with their lives World Disaster Report, (2001).

Early and adequate psychological intervention or support is a preventive factor and it helps people to cope better with their situations. It enhances the capacity of people to react effectively and to start reorganizing their lives. Neglecting emotional reactions may result in passive victims rather than active survivors and as a result the 
recovery process will be slow.

PTSD symptoms from any trauma are unlikely to disappear without psychological intervention and can contribute to depression, drug abuse and sleep problems that impede a person's ability to work and interact with others. Early psychological intervention therefore plays a key role in prevention of PTSD. World health organization (WHO) states that it is ethical to ascertain the extent and nature of any unmet psychological need after a disaster for psychological wellness. Cross professional work in mental health care teams for instance psychologists counselors and other health care teams need to be based at trauma sites to provide psychological support in the event of traumatic events ( Hobfoll et.,2007; Norris \& Elrod, 2006; Bonano, 2011; Dukers, 2013). Molika, (2004) concluded that a mental health system of psychological support providers if properly supported can provide cost-effective and good mental health care. The absence of psychological intervention following a traumatic event may lead to pathogenic elements in moving from normal reaction to a stressor to PTSD.

\section{Methodology}

Methodology describes the research design, study area and study population, sampling techniques and sample size, data collection tools and methods, data analysis and presentation. Descriptive survey and correlational designs formed the basis for this study.

Kombo \& Tromp (2007) contented that descriptive study involve measurement, classification, analysis, comparison and interpretation of data. Through this method, information is obtained using questionnaires and interviews to a sample of individuals rather than the entire population. Descriptive survey research design was ideal for the present study because the study endeavored to obtain information on what existed concerning Rationale for early psychological intervention among disaster actors.

Descriptive survey research design formed the basis for constructing research tools to solicit the desired information on the rationale for early psychological intervention among disaster actors, identifying individuals to be surveyed and the means to conduct the survey; and forming a basis for summarizing the collected data in a way that was to provide the desired descriptive information. The study also used correlational design that attempts to explore relationships to make predictions using one set of subjects with two or more variables for each. It helped to show the relationships between early psychological intervention and prevention of PTSD in disaster management.

\subsection{Sampling Techniques and sample size}

Sampling is concerned with the selection of a subject of individuals from within a statistical population to estimate characteristics of the whole population. Sampling is necessary where it is not possible to identify and measure every single item in the target study population and include any one of them in the sample. The study developed a sampling frame where a list of all respondents relevant to the study were made. Both probability and non- probability techniques were used in the study. Probability sampling is one in which every unit in the population has a chance to being selected in the sample.

Non-probability sampling is any sampling method where some elements of the population have no chance of selection or where the probability of selection cannot be accurately determined.

In the probability method, the stratified random sampling technique was used. This was important in the study to ensure that distinct categories in the sampling frame can be organized into separate strata where each stratum is then sampled as an independent sub- population, out of which individual elements can be randomly selected to classify the respondents. The respondent categories were by area of operation, those who are involved in rescue services, those who provide psychosocial support services and those who provide first aid.

Table 3.5: Study population units, sampling techniques

\begin{tabular}{|c|c|c|c|c|c|c|}
\hline $\begin{array}{l}\text { Study Population } \\
\text { (category }\end{array}$ & $\begin{array}{l}\text { population } \\
\text { unit }\end{array}$ & $\begin{array}{l}\text { Sampling } \\
\text { Technique }\end{array}$ & $\begin{array}{l}\text { Total } \\
\text { sample } \\
\text { size (N) }\end{array}$ & $\begin{array}{l}\text { No. of } \\
\text { study } \\
\text { units }\end{array}$ & $\frac{\text { Sample }}{\underline{\text { size }(n)}}$ & $\begin{array}{l}\underline{\text { Data collection }} \\
\underline{\text { instrument }}\end{array}$ \\
\hline \multirow[t]{2}{*}{ Disaster actors } & Rescue service & purposive & $\underline{65}$ & $\underline{3}$ & 7 & Questionnaire \\
\hline & & $\begin{array}{l}\text { stratified } \\
\text { random }\end{array}$ & $\underline{35}$ & $\underline{2}$ & $\underline{3}$ & Questionnaire \\
\hline $\begin{array}{l}\text { Paramedics/First } \\
\text { Aid }\end{array}$ & $\begin{array}{l}\text { Psychosocial } \\
\text { support }\end{array}$ & $\begin{array}{l}\text { Stratified } \\
\text { random }\end{array}$ & $\underline{20}$ & $\underline{1}$ & $\underline{2}$ & Questionnaire \\
\hline Directors/ Deputy & & purposive & $\underline{6}$ & $\underline{6}$ & & Interview guide \\
\hline
\end{tabular}


4. Results of the study

Table 4.0 Showing demographic data of directors and deputy directors.

\section{Variables}

Gender

$$
\text { i. Male }
$$

Position

i. Director

ii. Head of Department/deputy director

Occupation

i. Counseling psychology

ii. Fire Marshal

iii. Police Officer

iv. Security Officer

v. Head of Training

Unit/Department
i. St. Johns' Ambulance (Psychological counseling)
ii. NFRS (Fire rescue service)
iii. NDMU (Disaster Management Unit)
iv. KRCA (training department)
v. KCPA (counseling)

\begin{tabular}{|l|l|} 
Frequency & Percentage (\%) \\
\hline 6 & $100 \%$ \\
3 & $50 \%$ \\
3 & $50 \%$ \\
2 & \\
1 & $33.3 \%$ \\
1 & $16.7 \%$ \\
1 & $16.7 \%$ \\
1 & $16.7 \%$ \\
& $16.7 \%$ \\
& \\
1 & \\
1 & \\
2 & $16.7 \%$ \\
2 & $16.7 \%$ \\
\hline
\end{tabular}

Table 4.0 shows that the number of directors and deputy directors who were interviewed was the same $(50 \%)$ of which all were men. Directors Kenya counselors and psychologists Association (KCPA) were 2 (33.3\%), fire marshals, police officers, security officer and head of training each had $1(16.7 \%)$. Disaster Management Unit (NDMU) gave 2 directors which constituted the highest percentage $(33.3 \%)$ and the rest had 1 $(16.7 \%)$.

Table 4.1: Respondents background information by gender, unit/department, academic and work experience

\begin{tabular}{|c|c|c|c|}
\hline \multicolumn{2}{|c|}{ Variables } & Frequency & Percentage (\%) \\
\hline \multicolumn{4}{|c|}{ Gender } \\
\hline $\mathrm{i}$. & Male & 84 & $67.7 \%$ \\
\hline ii. & Female & 40 & $32.3 \%$ \\
\hline \multicolumn{4}{|c|}{ Unit/Department } \\
\hline i. & $\mathrm{KRC}$ & 11 & $8.8 \%$ \\
\hline ii. & NDOC & 19 & $15.3 \%$ \\
\hline iii. & NFS \& Ambulance & 23 & $18.5 \%$ \\
\hline iv & NDMU & 27 & $21.8 \%$ \\
\hline $\mathrm{v}$ & $\mathrm{KCPA}$ & 28 & $22.6 \%$ \\
\hline vi & St. Johns' Ambulance & 13 & $10.5 \%$ \\
\hline \multicolumn{4}{|c|}{ e } \\
\hline $\mathrm{i}$ & 18-24 Years & 14 & $11.3 \%$ \\
\hline ii & 25-34 Years & 39 & $31.5 \%$ \\
\hline iii & 35-44 Years & 28 & $22.6 \%$ \\
\hline iv & 45 Years and above & 43 & $34.7 \%$ \\
\hline \multicolumn{4}{|c|}{ Occupation } \\
\hline $\mathrm{i}$ & Driver & 1 & $0.8 \%$ \\
\hline ii & Police Officer & 37 & $29.8 \%$ \\
\hline iii & Fire marshal & 7 & $5.6 \%$ \\
\hline iv & Rescue Service Officer & 20 & $16.1 \%$ \\
\hline $\mathrm{v}$ & Ambulance Attendance & 9 & $7.3 \%$ \\
\hline vi & Counsellor & 30 & $24.2 \%$ \\
\hline vii & Social Workers & 3 & $2.4 \%$ \\
\hline viii & Other & 17 & $13.7 \%$ \\
\hline
\end{tabular}




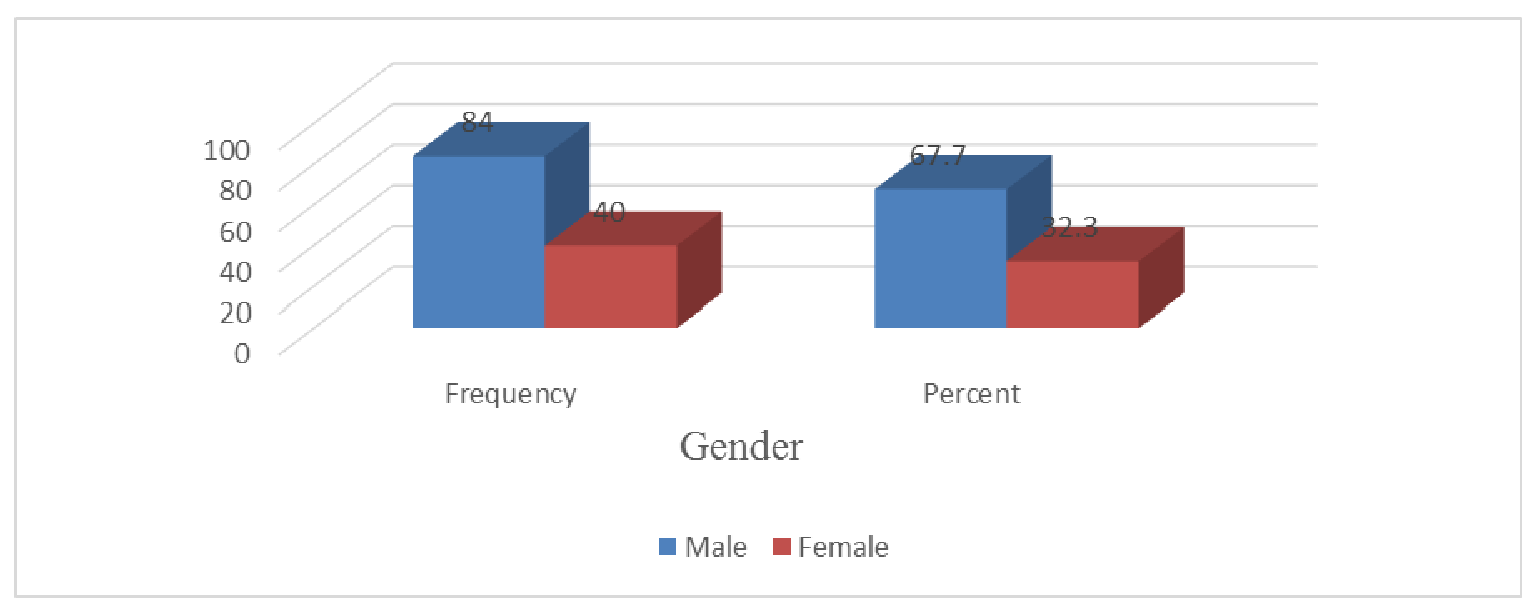

Figure 4.1 Frequency and percentage of gender of respondents

From figure 4.1 large number of actors who are active in providing disaster response services are men 84 $(67.7 \%)$ while women actors constitute a small number, $40(32 \%)$. Kenya counselors and psychological Association produced the highest number of respondents with $28(22.26 \%)$, followed by NDMU with 27 (21.8\%), NFS and St. Johns Ambulance 13 (10.5\%) and Kenya Red Cross Society 11 (8.8\%).

From the graph, the actors sample on gender could be summarized as not a good mixture of both male and female actors. The male dominated the number of respondents. To explain the above difference, the interviewed directors and deputy directors revealed that during recruitment more males are deployed in rescue services as compared to females in all organizations. It was also noted that most of those actors who provide psychosocial support were females. The researcher considers this not in line with the Kenya's constitution clause on affirmative action of 30 percent presentation (Kenya constitution, 2010).

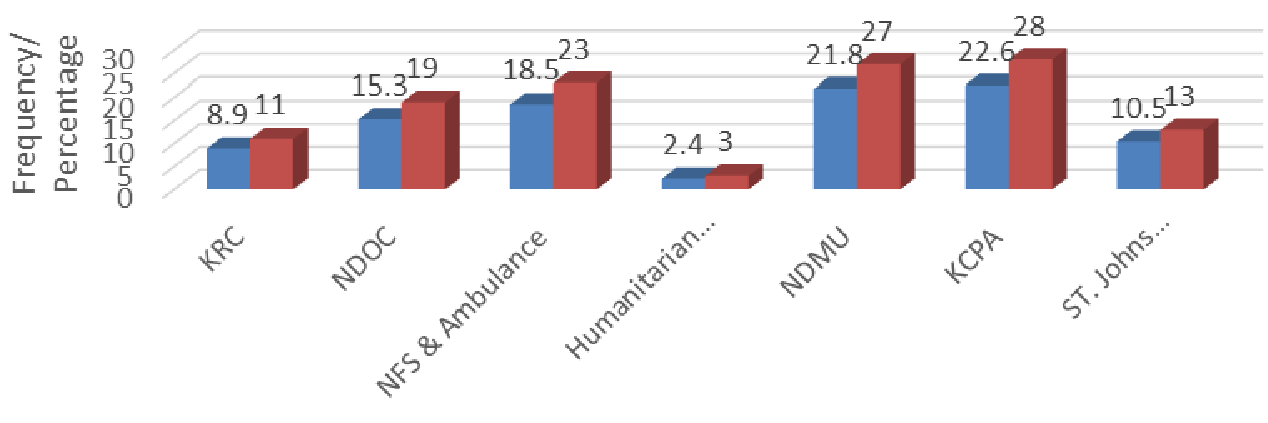

Department

a Percent $\boldsymbol{a}$ Frequency

Figure 4.1.1 Frequency and percentage of respondents from different departments

Figure 4.1.1 shows that Kenya counselors and psychological Association had the highest percentage in responding to disasters by providing psychosocial support among disaster actors for their psychological wellness. This was shown by a percentage of 22.6 with a frequency of 28 as compared to Kenya Red Cross with a percentage of 8.9 and St Johns Ambulance providing smaller percentage of services.

However, the impact of these services is little because most of the disaster operations organizations have no trauma counseling units nor do they have qualified mental health personnel like counselors and psychologists to provide trauma counseling in the event of disaster. 


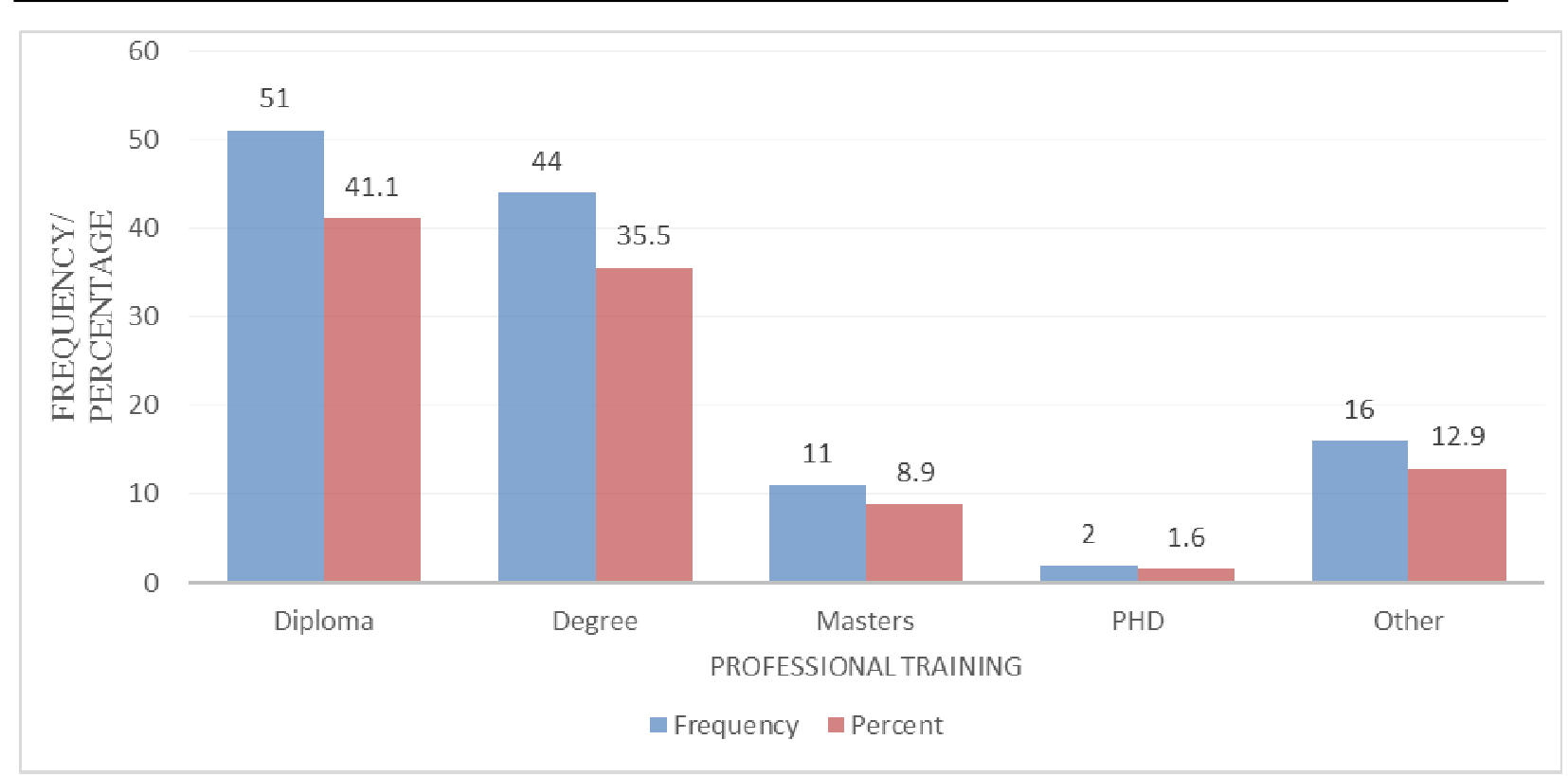

Figure 4.2: Actors Highest level of training

The demographic data on actors' academic level in the organizations under study was analyzed in relation to their highest academic level. Establishing the academic level of actors in the study sample was important to the study because it helped the researcher in understanding the work dynamics among the respondents. These dynamics were in academic level as which differs from one actor to another. Figure 4.2 describes that $51(41.1 \%)$ of the actor respondents were diploma holders, $44(35.5 \%)$ were degree holders, $11(8.9 \%)$ were masters holders and $2(1.6 \%)$ were PhD holders.

A total of $13(10.5 \%)$ respondents had masters and PHD, implying that professionals able to identify specific problems and solution while responding to disasters were limited. However highest number of actors academic qualification was diploma holders. Similar finding was recorded by WHO, 2013, "Adequate response to disasters require access to a pool of qualified and trained trauma professionals like counselors and psychologists or other mental health professionals who can provide evidence-supported interventions of verifying intensity in the event of disaster effectively". The study considered professional ism as the yardstick for the actors to be able to authoritatively comment on the issues under discussion.

\section{Conclusion}

The study sought to establish the rationale for early psychological intervention among disaster actors in disaster management. The data was collected through descriptive survey research design and the analysis employed exploratory method. The key respondents for the study were 124 disaster actors drawn from 6 disaster operations organizations in Nairobi County, Kenya. To validate data from the actors, the study involved other stakeholders namely 6 directors and deputy directors. The total number of study respondents was 130 .

The data from SPSS was thematically analyzed. Frequencies and percentages of the objective questions were prepared using the four-point likert scale and were analyzed under three sub-headings: competencies for personnel providing psychosocial support, training courses attended by the respondents and psychological intervention approaches used to prevent PTSD. As discussed in the literature review, early psychological support makes demands for those providing the services. They should have personal knowledge of the specific disaster, knowledge of its effects and knowledge of reactions to trauma and group dynamics. As professional counseling evolved, standards of practice were developed as means of solidifying professional identity and to help specific duties expected of the profession. (Dollar \& Saginak, 2012). To ascertain the adequacy of professional competencies in psychological support, the study respondents were given scenarios requiring the professional need. Data analysis was done, and the aspect surveyed here related to the issue of relevant skills.

To ensure that professionals who provide psychological support to disaster actors and survivors have adequate and sufficient training for the work and training programs have been instigated at all levels.

Psychological support and services should be availed for all those who experience traumatic events including survivors and actors immediately after the disaster. All this is to reduce the mental strain of individuals and should be prioritized in the early help efforts. Boscarino et., 2006 argued that early psychological first aid is recommended as a form of emergency mental health intervention to address the psychological needs for traumatized population in order to reduce advance outcomes. Screening should be undertaken 1-3 months after the disaster to ensure that effective treatment is available for people at risk followed by long-term follow-up for 
individuals who experience significant mental distress over time as a result of disaster. Lastly, the national disaster operation centre should coordinate country psychological support plans to ensure that responses to that require early psychological intervention following traumatic events are undertaken in a smooth and coordinated manner.

On the aspect of competencies of personnel providing early psychological intervention, the study findings revealed that most of the study respondents were positive that early psychological intervention would reduce posttraumatic stress symptoms hence preventing PTSD among disaster actors. The respondents had a view that their respective organizations needed to put in place trauma counseling units and deploy qualified counselors and psychologists to assist them deal with posttraumatic symptoms. The study thus concluded that there is a gap in providing psychological support among disaster actors where the disaster operations organizations appear to have left the actors to manage their stress after disasters without any professional intervention which may lead to PTSD. This was evident from data that showed that larger number of disaster actors never received any form of psychological support after responding to disasters like trauma counseling or psychological debriefing.

The basis for providing early psychological intervention among disaster actors was the fact that psychological intervention in the event of disasters was skewed to survivors.

Those who respond to disasters are left since it is assumed that they are trained to cope with difficult situations. The fact is that these professionals are not immune to trauma and PTSD. They have basic psychological needs for comfort and reassurance therefore lack of psychological support may lead to the actors becoming hidden victims. With reference to providing early psychological support like debriefing, actors appear to have great deficiency.

The findings thus identify felt need for providing psychological support for ventilation of emotions after responding to disasters. The study argues that the identification of the felt needs should be the reference point for developing an efficient psychological support programme. Secondly most of the disaster operations organizations under study did not have strategies for assisting the actors with psychological support.

The study made the following recommendation: Disaster operation organizations ensure that the actors are adequately provided with psychological support in the event of disasters. Key in this is the government having guidelines to avoid lack of support whenever it is needed. There is need to intensify psychological intervention among actors. This is because over ninety percent of disaster actor respondents attested the need.

Following disasters, survivors as well as disaster actors have the right to access appropriate psychological help and services. To guarantee this early psychological support has to be integrated in national laws and be part of all emergency plans. Action plans should be available on national level which includes coordination of psychological services, designating parties to be responsible of organizing and delivering psychological support and include psychological support services in emergency drill exercises.

From the interviews, the directors and deputy directors reported that there was need to provide early psychological intervention among disaster actors following traumatic events who may be hidden victims of trauma which may lead to PTSD. Psychological support should be provided immediately following disasters to help the actors who respond to the events ventilate out emotions for psychological wellness.

\section{References}

Alden, L. E., Regambal, M. J., \& Laposa, J. M. (2008). The effects of direct versus witnessed threat on emergency department healthcare workers: implications for PTSD criterion A. Journal of anxiety disorders, 22(8), 1337-1346.

American Psychiatric Association. (1994). Diagnostic and statistical manual of mental disorders. Washington Am Psychiatry Assoc, 143-146.

American Psychiatric Association. (2013). Diagnostic and Statistical Manual of Mental Health Disorders. 5thedn Washington. DC: American Psychiatric Association.

Arendt, M., \& Elklit, A. (2001). Effectiveness of psychological debriefing. Acta Psychiatrica Scandinavica, 104(6), 423-437.

Argentero, P., \& Setti, I. (2008). Job perception, work conditions and burnout in emergency workers. Giornale italiano di medicina del lavoro ed ergonomia, 30(1 Suppl A), A64-70.

Argentero, P., \& Setti, I. (2011). Engagement and vicarious traumatization in rescue workers. International Archives of Occupational and Environmental Health, 84(1), 67-75.

Barker, C., \& Pistrang, N. (2002). Psychotherapy and social support: Integrating research on psychological helping. Clinical Psychology Review, 22(3), 361-379.

Başoğlu, M., Livanou, M., \& Şalcıŏlu, E. (2003). A single session with an earthquake simulator for traumatic stress in earthquake survivors. American Journal of Psychiatry, 160(4), 788-790.

Beaton, R., Murphy, S., Johnson, C., Pike, K., \& Corneil, W. (1999). Coping responses and posttraumatic stress symptomatology in urban fire service personnel. Journal of traumatic stress, 12(2), 293-308.

Bland, M. (2015). An introduction to medical statistics. Oxford University Press (UK). 
Bradley, R., Greene, J., Russ, E., Dutra, L., \& Westen, D. (2005). A multidimensional meta-analysis of psychotherapy for PTSD. American journal of Psychiatry, 162(2), 214-227.

Brady, K. T., Killeen, T. K., Brewerton, T., \& Lucerini, S. (2000). Comorbidity of psychiatric disorders and posttraumatic stress disorder. The Journal of clinical psychiatry.

Breslau, N., Davis, G. C., Andreski, P., Peterson, E. L., \& Schultz, L. R. (1997). Sex differences in posttraumatic stress disorder. Archives of general psychiatry, 54(11), 1044-1048.

Breslau, N., Peterson, E. L., Poisson, L. M., Schultz, L. R., \& Lucia, V. C. (2004). Estimating post-traumatic stress disorder in the community: lifetime perspective and the impact of typical traumatic events. Psychological medicine, 34(5), 889-898.

Brophy, J. (2013). Motivating students to learn. Routledge.

Caplan, G. (1998) Principles of preventive psychiatry: PTSD in ambulant RTA Victims. Randomized controlled trial of debriefing. Journal of Psychiatric Research, 46, 37-44.

Chermack, T. J., \& Kasshanna, B. K. (2007). The use and misuse of SWOT analysis and implications for HRD professionals. Human Resource Development International, 10(4), 383-399.

Chorzempa, B. F., \& Lapidus, L. (2009). To find yourself, think for yourself. Teaching Exceptional Children, 41(3), 54-59.

Cochrane Database of Systems Rev (2008). Psychological interventions for Prevention of psychological disorders in the law enforcement officers: Managing after-effects of disaster trauma in the essentials of early intervention.

Conlon, L., Fahy, T. J., \& Conroy, R. (1999). PTSD in ambulant RTA victims: A randomized controlled trial of debriefing. Journal of psychosomatic research, 46(1), 37-44.

Cook-Vienot, R., \& Taylor, R. J. (2012). Comparison of eye movement desensitization and reprocessing and biofeedback/stress inoculation training in treating test anxiety. Journal of EMDR Practice and Research, $6(2), 62-72$.

Corey, G. (2013). Theory and practice of counseling and psychotherapy ( $9^{\text {th }}$ ed.). California: Brook/Cole, Cengage Learning

Cornell, A. W. (1996). The power of focusing: A practical guide to emotional self-healing. Oakland, CA: New Harbinger Publications.

County Government of Nairobi (2015). Nairobi City County fire and rescue Services. Nairobi Government Printer.

Davis III, T. E., Grills-Taquechel, A. E., \& Ollendick, T. H. (2010). The psychological impact from hurricane Katrina: Effects of displacement and trauma exposure on university students. Behavior therapy, 41(3), 340349.

DeWolfe, D. J. (2000). Field Manual for Mental Health and Human Service Workers in Major Disasters.

Dittman, M. (2005). After the wave. Monitor on Psychology, 36(3), 36.

Dougal, A. L., Hyman, K. B., Hayward, M. C., McFeeley, S., \& Baum, A. (2001). Optimism and Traumatic Stress: The Importance of Social Support and Coping 1. Journal of Applied Social Psychology, 31(2), 223245.

Duckers, M. L. (2013). Five essential principles of post-disaster psychosocial care: Looking back and forward with Stevan Hobfoll. European journal of psychotraumatology, 4(1), 21914.

Dyb, G., Jensen, T. K., Nygaard, E., Ekeberg, Ø., Diseths, T. H., Wentzel-Larsen, T., \& Thoresen, S. (2014). Post-traumatic stress reactions in survivors of the 2011 massacre on Utøya Island, Norway. The British Journal of Psychiatry, 204(5), 361-367.

Dynes, R. and Russel, N. (2002) A prospective on disaster planning: Delaware Disaster Research Centre.

European Federation of Psychologists' Associations (2009). Lessons learned in psychosocial care after disasters. Retrieved July 19,2013, from http: // disaster. Efpa.eu/ recent- reports/ lessons-learned-( 1999-2004). Evaluation of 20 years of use. Psychosomatic Medicine, 65,870-87.

Falsetti, A. (2003). Cognitive behavioral therapy in the treatment of post-traumatic stress disorder. Primary Psychiatry, 10, 78-83.

Field, A. (2005). Discovering Statistics Using SPSS (Introducing Statistical Methods) Sage Publications, London.

Fisher, R., \& Shapiro, D. (2005). Beyond reason: Using emotions as you negotiate. Penguin.

Forbes, D., Fletcher, S., Wolfgang, B., Varker, T., Creamer, M., Brymer, M. J., ... \& Bryant, R. A. (2010). Practitioner perceptions of Skills for Psychological Recovery: a training programme for health practitioners in the aftermath of the Victorian bushfires. Australian \& New Zealand Journal of Psychiatry, 44(12), 11051111.

Foy, D. W., Drescher, K. D., Fitz, A. G., \& Kennedy, K. R. (2003). 13. Post-Traumatic Stress Disorder. Clinical handbook of pastoral counseling, 3, 274.

Freedman, D., Pisani, R. and Purves, R. (2007) Statistics (4 ${ }^{\text {th }}$ ed.). New York: Norton. ISBN 393-929.

Friedmam, M. (2015). PTSD history and overview. National Center for PTSD. Retrieved from 
https://www.ptsd.va.gov/professional/ptsd-overview/ptsdoverview.asp

Fukasawa, Y. (2002, August). Enhancing capacity of managing disaster in local government leaders. In Regional workshop on total disaster risk management, Kobe, Japan (pp. 7-9).

Fullerton, C. S., Ursano, R. J., \& Wang, L. (2004). Acute stress disorder, posttraumatic stress disorder, and depression in disaster or rescue workers. American Journal of Psychiatry, 161(8), 1370-1376.

Funk, M. (2012). Global burden of mental disorders and the need for a comprehensive, coordinated response from health and social sectors at the country level.

Fussell, E., \& Lowe, S. R. (2014). The impact of housing displacement on the mental health of low-income parents after Hurricane Katrina. Social Science \& Medicine, 113, 137-144.

Galea, S., Nandi, A., \& Vlahov, D. (2005). The epidemiology of post-traumatic stress disorder after disasters. Epidemiologic reviews, 27(1), 78-91.

Gorman, W. (2001). Refugee survivors of torture: Trauma and treatment. Professional Psychology: Research and Practice, 32(5), 443.

Green, B. L., Lindy, J. D., Grace, M. C., Gleser, G. C., Leonard, A. C., Korol, M., \& Winget, C. (1990). Buffalo Creek survivors in the second decade: Stability of stress symptoms. American journal of orthopsychiatry, 60(1), 43-54.

Hiley B. \& Meyers, D. (1996). Disaster Response and Recover: A Handbook for Mental Health Professionals. DIANE publishing.

Hobfoll, S. E., Watson, P., Bell, C. C., Bryant, R. A., Brymer, M. J., Friedman, M. J., ... \& Maguen, S. (2007). Five essential elements of immediate and mid-term mass trauma intervention: Empirical evidence. Psychiatry: Interpersonal and Biological Processes, 70(4), 283-315.

Hogan, B. E., Linden, W., \& Najarian, B. (2002). Social support interventions: Do they work? Clinical psychology review, 22(3), 381-440.

Hulley, S. B. (Ed.). (2007). Designing clinical research. Lippincott Williams \& Wilkins.

Humphrey, A. (2005). SWOT analysis for management consulting. SRI alumni Newsletter, 1, 7-8.

Inter- Agency Standing Committee (IASC) (2007) IASC Guidelines on mental Health and psychosocial support in emergency settings. Geneva: IASC

Inter-Agency Standing Committee. (2006). IASC guidelines on mental health and psychosocial support in emergency settings. Geneva, Switzerland: IASC 2006.

Inter-Agency Standing Committee. (2010). Mental Health and Psychosocial Support in Humanitarian Emergencies: What Should Humanitarian Health Actor Know? In Mental Health and Psychosocial Support in Humanitarian Emergencies: What Should Humanitarian Health Actor Know? Inter-Agency Standing Committee (IASC). Reference Group for Mental Health and Psychosocial Support in Emergency Settings.

International Association of Fire Fighters (2000) Death \& injury survey Washington DC.

Jacob, K. S., Sharan, P., Mirza, I., Garrido-Cumbrera, M., Seedat, S., Mari, J. J., ... \& Saxena, S. (2007). Mental health systems in countries: where are we now? The Lancet, 370(9592), 1061-1077.

Jean, D.M. (2012). The ripple effects of trauma. Victims, perpetrators and criminal justice systems. Carolina: Spinfox Press.

Johnson, B.and Eid, J. (2007) Posttraumatic symptoms in non-exposed victims and spontaneous rescuers after Avalanche.

Jonsson, A., \& Segesten, K. (2004). Guilt, shame and need for a container: a study of post-traumatic stress among ambulance personnel. Accident and emergency nursing, 12(4), 215-223.

Kaniasty, K., \& Norris, F. H. (2000). Help-seeking comfort and receiving social support: The role of ethnicity and context of need. American journal of community psychology, 28(4), 545-581.

Katz, C. L., Pellegrino, L., Pandya, A., Ng, A., \& DeLisi, L. E. (2002). Research on psychiatric outcomes and interventions subsequent to disasters: a review of the literature. Psychiatry research, 110(3), 201-217.

Kerig, P. K., \& Ford, J. D. (2014). Trauma among girls in the juvenile justice system. National Child Traumatic Stress Network, http://www. nctsn. org.

Kerlinger, F. and Lee, H. (2000) Foundations of Behavioral Research. Harcourt College Publishers, New York.

Kessler, R. C., Sonnega, A., Bromet, E., Hughes, M., \& Nelson, C. B. (1995). Posttraumatic stress disorder in the National Comorbidity Survey. Archives of general psychiatry, 52(12), 1048-1060.

Koch, A. J. (2000). SWOT does not need to be recalled: It needs to be enhanced. B quest, 1(1), 1.

Kombo, D. K., \& Tromp, D. L. (2006). Proposal and thesis writing: An introduction. Nairobi: Paulines Publications Africa, 5, 814-30.

Kothari, C. R. (2004). Research methodology: Methods and techniques. New Age International.

Lalić, H., Bukmir, L., \& Ferhatović, M. (2007). Examining psychic consequences in firefighters exposed to stress. Collegium antropologicum, 31(2), 451-455.

Lange-Altman, T. (2015). Seeking safety and the social model of addictions treatment: A comparison study for the homeless, addicted, and traumatized (Doctoral dissertation, Spalding University). 
Leedy, P. D., \& Ormrod, J. E. (2005). Practical research: plan and design.

Levesque, R. (2005). SPSS programming and data management: a guide for SPSS and SAS users. Spss.

Lin, I. Y., \& Mattila, A. S. (2010). Restaurant services cape, service encounter, and perceived congruency on customers' emotions and satisfaction. Journal of hospitality marketing \& management, 19(8), 819-841.

Litz, B. T., Gray, M. J., Bryant, R. A., \& Adler, A. B. (2002). Early intervention for trauma: Current status and future directions. Clinical psychology: science and practice, 9(2), 112-134.

Lock, S; Rubin, G; Murray, V, et al. (2012). Secondary Stress and Extreme Events and Disasters: A Systematic Review of Primary Research from 2010-2011. PLoS Current.4.

Maia, D. B., Marmar, C. R., Metzler, T., Nóbrega, A., Berger, W., Mendlowicz, M. V., ... \& Figueira, I. (2007). Post-traumatic stress symptoms in an elite unit of Brazilian police officers: Prevalence and impact on psychosocial functioning and on physical and mental health. Journal of affective disorders, 97(1-3), 241245.

McCann, I. L., \& Pearlman, L. A. (1990). Vicarious traumatization: A framework for understanding the psychological effects of working with victims. Journal of traumatic stress, 3(1), 131-149.

McCann, I. L., \& Pearlman, L. A. (1992). Constructivist self-development theory: A theoretical framework for assessing and treating traumatized college students. Journal of American College Health, 40(4), 189-196.

McEntire, D. A., \& Marshall, M. (2003). Epistemological problems in emergency management: Theoretical dilemmas and implications. Aspep Journal, 10, 119-129.

McEntire, D. A., \& Marshall, M. (2003). Epistemological problems in emergency management: Theoretical dilemmas and implications. Aspep Journal, 10, 119-129.

McGuire, A.; Richardson \& Coghill, e. (2007). Implementation and evaluation of critical care counseling. American Journal of Psychology and Nursing.

Menya, A. A., \& K'Akumu, O. A. (2016). Inter-agency collaboration for fire disaster management in Nairobi City. Journal of Urban Management, 5(1), 32-38.

Meyer, E. C., Zimering, R., Daly, E., Knight, J., Kamholz, B. W., \& Gulliver, S. B. (2012). Predictors of posttraumatic stress disorder and other psychological symptoms in trauma-exposed firefighters. Psychological services, 9(1), 1.

Ministry of Health: Mental Health Training Manual for Community Health Extension Workers ( $1^{\text {st }}$ ed.) 2016

Mitchell, J. T., \& Everly, G. S. (2000). Critical incident stress management and critical incident stress debriefings: Evolutions, effects and outcomes. Psychological debriefing: Theory, practice and evidence, 7190.

Mollica, R. F., Cardozo, B. L., Osofsky, H. J., Raphael, B., Ager, A., \& Salama, P. (2004). Mental health in complex emergencies. The Lancet, 364(9450), 2058-2067.

Moore, D \& Cabe, G. (2005). "Introduction to the practice of statistics" (5 $5^{\text {th }}$ ed.) W.H. Freeman \& Company. ISBN 0-7167- 6282-X.

Mugenda, O. M., \& Mugenda, A. G. (2003). Qualitative and quantitative approaches. Research Methods Africa Center for Technology Studies (Acts) Press. Nairobi Kenya.

Muno, R. (2012). Trauma-focused therapy. Los Angeles: National Child Traumatic Stress Network.

Mwenda, A. K. (2010). Economic and administrative implications of the devolution framework established by the constitution of Kenya.

Myrick \& Henderson. (2006). Models for counseling in post disaster. Major disasters. Wahington DC: Department of Health and Human Services. National Center for PTSD (2003) Assessment Instruments. http: //www.

Neria Y, Galea, S. Norris F,editors. Mental health and disasters. Cambridge: University Press; pp. 366-384.

Neuner, F.,Karunakara, U. \& Ebert, T. (2004) A comparison of narrative exposure Therapy, supportive counseling and psycho-education for treating Posttraumatic Stress Disorder in an African refugee settlement. Journal Counseling and Clinical Psychology, 72, 579-587

Norris, F. H., \& Elrod, C. L. (2006). Psychosocial consequences of disaster. Methods for disaster mental health research, 20-42.

Norris, F. H., Friedman, M. J., \& Watson, P. J. (2002). 60,000 disaster victims speak: Part II. Summary and implications of the disaster mental health research. Psychiatry: Interpersonal and biological processes, 65(3), 240-260.

Norris, F. H., Friedman, M. J., \& Watson, P. J. (2002). 60,000 disaster victims speak: Part II. Summary and implications of the disaster mental health research. Psychiatry: Interpersonal and biological processes, 65(3), 240-260.

North, C. S., Oliver, J., \& Pandya, A. (2012). Examining a comprehensive model of disaster-related posttraumatic stress disorder in systematically studied survivors of 10 disasters. American journal of public health, 102(10), e40-e48.

North, C.; Oliver, J \& Pandya, A. (2012). Examining a comprehensive model of disaster-related posttraumatic 
stress disorder in systematically studied survivors of 10 disasters. American Journal of Public Health. 102 (10): 40-48.

Okpalaenwe, E. (2014). Psychological counseling for Africa: A handbook counseling in Africa contexts. Nairobi: CUEA Press.

Orodho, A. J. (2003). Essentials of educational and social science research methods. Nairobi: Masola Publishers.

Ozer, E. J., Best, S. R., Lipsey, T. L., \& Weiss, D. S. (2003). Predictors of posttraumatic stress disorder and symptoms in adults: a meta-analysis. Psychological bulletin, 129(1), 52.

Ozer, E. J., Best, S. R., Lipsey, T. L., \& Weiss, D. S. (2003). Predictors of posttraumatic stress disorder and symptoms in adults: a meta-analysis. Psychological bulletin, 129(1), 52.

Ozer, E. J., Best, S. R., Lipsey, T. L., \& Weiss, D. S. (2003). Predictors of posttraumatic stress disorder and symptoms in adults: a meta-analysis. Psychological bulletin, 129(1), 52.

Patton, M.Q. (2002) Qualitative evaluation and research methods ( ${ }^{\text {rd }}$ ed.) Thousand Oaks, CA: Sage Publications, Inc.

Peñalba, V., McGuire, H., \& Leite, J. R. (2008). Psychosocial interventions for prevention of psychological disorders in law enforcement officers. Cochrane Database of Systematic Reviews, (3).

Perkonigg, A., Kessler, R. C., Storz, S., \& Wittchen, H. U. (2000). Traumatic events and post-traumatic stress disorder in the community: prevalence, risk factors and comorbidity. Acta psychiatrica scandinavica, 101(1), 46-59.

Post-traumatic stress disorder. (2016). National Institute of Mental Health. Retrieved from https://www.nimh.hih.gov/health/topics/post-traumatic-sress-disorder-ptsd/index.shtml

Prati, G., Saccinto, E., Pietrantoni, L., \& Pérez-Testor, C. (2013). The 2012 Northern Italy earthquakes: modelling human behaviour. Natural hazards, 69(1), 99-113.

Preston, J., O'Neal, J. H., \& Talaga, M. C. (2010). Handbook of clinical psychopharmacology for therapists. New Harbinger Publications.

Professionals on mental health response after disasters. (2003). Association for psychological science.

Professionals on mental health response after disasters. (2003). Association for psychological science

R. Wind, T., Fordham, M., \& H. Komproe, I. (2011). Social capital and post-disaster mental health. Global health action, 4(1), 6351.

Raphael \& Evelyn. (2000). Effects of early psychological interventions after disasters.

Raphael, B., \& Wilson, J. (Eds.). (2000). Psychological debriefing: Theory, practice and evidence. Cambridge University Press.

Regehr, C. (2009). Social support as a mediator of psychological distress in firefighters. The Irish Journal of Psychology, 30(1-2), 87-98.

Regehr, C., Johanis, D., Dimitropoulos, G., Bartram, C., \& Hope, G. (2003). The Police Officer and the Public Inquiry: A Qualitative Inquiry into the Aftermath of Workplace Trauma. Brief Treatment \& Crisis Intervention, 3(4).

Reifels, L., Pietrantoni, L., Prati, G., Kim, Y., Kilpatrick, D. G., Dyb, G., ... \& O'donnell, M. (2013). Lessons learned about psychosocial responses to disaster and mass trauma: An international perspective. European journal of psychotraumatology, 4(1), 22897.

Rose, S., Brewin, C. R., Andrews, B., \& Kirk, M. (1999). A randomized controlled trial of individual psychological debriefing for victims of violent crime. Psychological Medicine, 29(4), 793-799.

Rubonis, A. V., \& Bickman, L. (1991). Psychological impairment in the wake of disaster: The disasterpsychopathology relationship. Psychological bulletin, 109(3), 384

Satel, S. (2005). Bread and Shelter, Yes, Psychiatrists, No. The New York Times, F5.

Saxena, S., Funk, M., \& Chisholm, D. (2014). WHO's Mental Health Action Plan 2013-2020: what can psychiatrists do to facilitate its implementation? World Psychiatry, 13(2), 107-109.

Schellenberg, R. Parks, S. and Rehfuss, A. (2007) Professional School Counseling Psychology and Mental Health. American School Counselor Association. Volume: 10 Source Issue: 5 ISSN: 1096-2409.

Siele, S. (2010) Students Hurt in Fire Incident. Daily Nation p.16., Nairobi, Kenya.

Skogstad, M., Skorstad, M., Lie, A., Conradi, H. S., Heir, T., \& Weisæth, L. (2013). Work-related post-traumatic stress disorder. Occupational medicine, 63(3), 175-182.

Sphere Project. (2004). Humanitarian charter and minimum standards in disaster response. Sphere Project.

Stern, D. T., \& Papadakis, M. (2006). The developing physician-becoming a professional. New England Journal of Medicine, 355(17), 1794-1799.

Sundin, E. C., \& Horowitz, M. J. (2003). Horowitz's Impact of Event Scale evaluation of 20 years of use. Psychosomatic medicine, 65(5), 870-876.

Suzuki, Y., \& Kim, Y. (2012). The great east Japan earthquake in 2011; toward sustainable mental health care system. Epidemiology and psychiatric sciences, 21(1), 7-11.

Taylor, S., Thordarson, D. S., Maxfield, L., Fedoroff, I. C., Lovell, K., \& Ogrodniczuk, J. (2003). Comparative 
efficacy, speed, and adverse effects of three PTSD treatments: exposure therapy, EMDR, and relaxation training. Journal of consulting and clinical psychology, 71(2), 330.

Thürer, D. (2007). Dunant's pyramid: thoughts on the "humanitarian space". International Review of the Red Cross, 89(865), 47-61.

Trautman, R., Tucker, P., Pfefferbaum, B., Lensgraf, S. J., Doughty, D. E., Buksh, A., \& Miller, P. D. (2002). Effects of prior trauma and age on posttraumatic stress symptoms in Asian and Middle Eastern immigrants after terrorism in the community. Community Mental Health Journal, 38(6), 459-474.

Trochim, W. 92006). Research Methods Knowledge Base. London. SAGE. Available at http://www.sagepub.com/upm-data/41165-10.pdf. Accessed on $24^{\text {th }}$ July 2014.

Udwin, O. and Yule, W. (2000) Risk factors for long-term psychological effects of a disaster experienced in adolescence: Predictors of Post- Traumatic Stress Disorder. Journal of Child Psychology and Psychiatry, 41,969-979.

UNISDR (2002) How to make Cities more resilient: A Handbook for Local Government Leaders.

Van der Kolk, B. A., \& McFarlane, A. C. van der hart, O.(1996). A general approach to treatment of posttraumatic stress disorder. In. BA van der Kolk, AC McFarlane, and L. Weisaeth (Eds.), Traumatic stress: The effects of overwhelming experience on mind, body and society, 417-440.

van der Kolk, B. A., Spinazzola, J., Blaustein, M. E., Hopper, J. W., Hopper, E. K., Korn, D. L., \& Simpson, W. B. (2007). A randomized clinical trial of eye movement desensitization and reprocessing (EMDR), fluoxetine, and pill placebo in the treatment of posttraumatic stress disorder: treatment effects and long-term maintenance. Journal of clinical psychiatry, 68(1), 37.

Van der Ploeg, E., \& Kleber, R. J. (2003). Acute and chronic job stressors among ambulance personnel: predictors of health symptoms. Occupational and environmental medicine, 60(suppl 1), i40-i46.

Van Emmerik, A. A., Kamphuis, J. H., Hulsbosch, A. M., \& Emmelkamp, P. M. (2002). Single session debriefing after psychological trauma: a meta-analysis. The Lancet, 360(9335), 766-771.

Vila, G., Witkowski, P., Tondini, M. C., Perez-Diaz, F., Mouren-Simeoni, M. C., \& Jouvent, R. (2001). A study of posttraumatic disorders in children who experienced an industrial disaster in the Briey region. European Child \& Adolescent Psychiatry, 10(1), 10-18.

Wagner, D., Heinrichs, M., \& Ehlert, U. (1998). Prevalence of symptoms of posttraumatic stress disorder in German professional firefighters. American journal of psychiatry, 155(12), 1727-1732.

Walsh, L., Subbarao, I., Gebbie, K., Schor, K. W., Lyznicki, J., Strauss-Riggs, K., ... \& Hick, J. (2012). Core competencies for disaster medicine and public health. Disaster medicine and public health preparedness, 6(1), 44-52.

Wang, C; Chan, C \& Ho, R. (2013). Prevalence and Trajectory of Psychopathology among Child and Adolescent Survivors of Disaster: A systematic Review of Epidemiological Studies across 1987-2011. Social Psychiatry and Psychiatric Epidemiology. 48(11): 1697-1720

Watson, P. J., Brymer, M. J., \& Bonanno, G. A. (2011). Post disaster psychological intervention since 9/11. American Psychologist, 66(6), 482.

Watson, P. J., Brymer, M. J., \& Bonanno, G. A. (2011). Post disaster psychological intervention since 9/11. American Psychologist, 66(6), 482.

Westhues, A., Lafrance, J., \& Schmidt, G. (2001). A SWOT analysis of social work education in Canada. Social Work Education, 20(1), 35-56.

Westphal, M. and Bonanno, G. (2014) Traumatization and PTSD in rescue workers: Prevention, assessment and intervention.

What is posttraumatic stress disorder? (2013). American Psychiatric Association. Retrieved from https://www.psychiatry.org/patients-families/ptsd/what-is-ptsd.

Winter, G. (2000). A comparative discussion of the notion of "validity in qualitative and quantitative research. The qualitative report, 4(3), 1-14.

Wooding, S., \& Raphael, B. (2004). Psychological impact of disasters and terrorism on children and adolescents: experiences from Australia. Prehospital and disaster medicine, 19(1), 10-20.

World Health Organization. (2008). Integrating mental health into primary care: a global perspective.

Yilmaz, V. (2004). A statistical analysis of the effects on survivors of the 1999 earthquake in Turkey. Social Behavior and Personality: an international journal, 32(6), 551-558.

Yule, W. (2006) Research on psychological intervention in complex emergencies Professionals on mental health response after disasters: Association for Psychological Science.

Zimmerman, M. A., Ramirez-Valles, J., Zapert, K. M., \& Maton, K. I. (2000). A longitudinal study of stress-buffering effects for urban African American male adolescent problem behaviors and mental health. Journal of community psychology, 28(1), 17-33. 